\title{
Fibroblast Growth Factor 19
}

National Cancer Institute

\section{Source}

National Cancer Institute. Fibroblast Growth Factor 19. NCI Thesaurus. Code C96330.

Fibroblast growth factor 19 (216 aa, 24 kDa) is encoded by the human FGF19 gene. This protein is involved in the modulation of intercellular communication. 